\title{
喉頭治療（I） 12１5
}

\section{座長のまとめ}

この群は喉頭癌一次治療の成績についての報告で当然 照射療法で制禦されなかった例が対象となった。すでに 根治照射の適応は $T_{1}, T_{2}$ とされ, それも声門上癌に対 しては厳しく解釈され, また前連合部癌・潰瘍形成ある もの・披裂部の浮腫ある場合および角化傾向を示す扁平 上皮癌に対しては照射療法の限界も指摘されている。し かし喉頭保存率は同時に考慮される心゙き問題であり，ま た照射適応例の中にも一次治療不成功例も少なくない。 また部切の機能にも限度あるなど問題は多い。

本群を通して声門癌 $\mathrm{T}_{3}, \mathrm{~T}_{4}$ に対しては手術を優先せ ることには問題ないとされながらも $\mathrm{T}_{3} \mathrm{~N}_{0}$ の照射によ る原発条制禦率70\%とし，4000 rad の時点の計画的手術 を用意しつつ放射線主体の治療を推進している処もある (北大)。しかしこの場合でも声門上癌の照射有効率が 対照的に低く，また声門上癌の比率が他施設に比べて著 しく高率に出ているが，このことがどの様に関係してい るであらうか。
本多 芳男 (東京慈恵会医科大学・耳鼻咽喉科)

それでも声門癌においては治療効果も良く, 腫瘍病態 と照射の効果の関係も納得できるし再発時の salvage 手 術にも期待できる。一方声門上癌では全般的に一次治療 の効果が低く $T_{1}, T_{2}$ でも原発巣制禦に苦しむことは少 なくない。しかし反面声門上癌の Stage III, IV でも喉 頭保存が $41 \% ， 24 \%$ の成績であり（国立ガンセンター） 同センターの声門癌 Stage III，IV では夫々 $22 \%, 0 \%$ となっている。理由は不明であるが声門上癌の進行癌の 喉頭保存率が良いのは今後治療上の参考としたい。

只一般耳鼻咽喉科医が注意したいのは声門上癌のT決 定の確実な方法である。前方発育型では喉頭蓋基部より pre-epiglottic space 一と更に喉頭外一進展し易く, $\mathrm{T}_{1}$ と思われたタイプが検查の進行につれて $\mathrm{T}_{2}$ となり更ら に $\mathrm{T}_{4}$ へと変わって行ったことを我々は経験している。 $\mathrm{CT}$ その他の最近の検查器具を動員してTの確実な決定 を行っておかないと比較対象に苦しむのみか, 治療方針 の誤まりを招く。 


\title{
12. 当教室における喉頭癌の治療成績と再発の検討
}

\author{
穎川 一信・加藤 孝邦・本多 芳男 \\ （東京慈恵会医科大学 $\cdot$ 耳鼻咽喉科）
}

昭和 51 年 4 月より昭和 57 年 4 月までの 6 年間に当科に て治療した喉頭癌末治療109例について 検討した。

Glottic 72例, Supraglottic 30例, subglottic 7 例, Glottic-stage I 33 例, stage II 19例, stage III 15 例, stage IV 5 例。Supraglottic-stage I 6 例, stage II 3 例, stage III10例, stage IV 11例。Subglottic-stage I 1例, stage II 2 例, stage III 3 例, stage IV 1 例。頸部リン パ節転移率, Glottic $11.1 \%$, Supraglottic $40 \%$, Subglottic $14.3 \%$ 。

平均年齢 : Glottic 65歳, Supraglottic 70歳, 50 歳以下 は全例 Glottic であり, Supraglottic がやや高齢者に偏 位していた。女性 7 名, Supraglottic 4 名, Glottic 3 名 であった。

治療方針 : stage I, II では照射中心, stage III, IV は手術中心としたが，近年では, Supraglottic で, 腫瘍 の原発部位, 大きさによって stage I でも手術を行なっ ている。

累積生存率: 全体， 3 年 $74.5 \% ， 5$ 年 $70.0 \%$ 。 stage I，II，IIIはほぼ同様の傾向を示すが， stage IVは，3 年 5 年ともに $27.7 \%$ と他にくらべて治療成績が著しく振 わなかった。また，Glottic は1〜2 年で生存率は一定 し，88.4\%であったが，Supraglottic では生存率は 5 年 で直線的に下降し，3 年50\%，5年 $35 \%$ であった。

死 因: Supraglottic, 原発栄 4 例, 顓部リンパ節 5 例 遠隔転移 4 例，他病死 2 例，手術死 1 例。Glottic，頸 部リンパ節 3 例, 他病死 3 例, 手術死 1 例, 不明 1 例。Subglottic, 原発巣 1 例, 頸部リンパ節 1 例, 遠隔転移 1例。原病死率は Supraglottic が Glottic にくらべて 高い。また，高齡化にともない他病死が増加している。

再発: Glottic では 2 年までの早期再発がみられたが, Supraglottic では 5 年までの晚期再発む認められ，長期 の経過観察が必要である。一次治療後の再発率は Glottic $14.5 \%$, Supraglottic 53.6\%, Subglottic $83.3 \%$ で あり, Supraglottic と Subglottic の再発率が非常に高 く, 治療方針の再検討を痛切に感じた。

Glottic の stage I， II で照射単独による局所再発が 7 例あり，6例は salvage ope にて制御されており，再
発後のコントロールはしやすいと思う。

Subglottic では照射単独の 4 例全例が再発し， 2 例が 制御されている。症例は少ないのですが，根治照射はむ ずかしいと思う。

Supraglottic では, stage I で6例中 3 例が再発し, 喉頭蓋原発の 2 例が死亡した。 stage II では 3 例全例が 再発し, salvage ope にてすべて制御され，3 例共に仮声 帯原発であった。 stage I， IIでは，仮声帯原発症例は 喉頭蓋原発症例よりも再発後のコントロールがしやすい と思われた。また,根治照射で現在制御されているのは， 喉頭蓋先端の 1 症例のみで, 他は全例再発している。

二次治療後の制御率は, Glottic $60 \%$, Supraglottic 20 \%, Subglottic $40 \%$ であり, Supraglottic は, salvage ope にてほとんど制御されがたく，あらためて一次治療 の重大さを感じた。

Surpaglottic：a）舌骨より上方の喉頭蓋後面 1 例, b）披裂喉頭蓋七ダ 2 例， c ）披裂部 2 例，d）舌骨よ り下方の喉頭蓋12例，e）仮声帯 13 例であり，d）の 3 年粗生存率 $25 \%$, e ) は $75 \%$ と, 喉頭蓋原発が仮声带原 発にくらべて生存率が低いことが認められた。また，喉 頭蓋前庭部癌は非常に preepigolottic space 一浸入しや すくわれわれの症例では約半数にみられ，また，肺に 転移した 3 例共に喉頭蓋原発であった。よってこの部位 に対しては, 術前の十分な腫瘍進展の確認と十分な郭清 が必要であり，そのためにも CT は重要な検査であり ます。

結 語 : Supraglottic では喉頭蓋原発と仮声帯原発で 治療成績に差がみられた。よって, Supraglottic は Glottic 㳊対する治療方針とは異なり，症例ごとの治療選択 が必要である。つまり，Glottic に対しては, stage I, II は照射中心，III，IVは手術中心とする今までの方針で 行なう。Supraglottic では, 喉頭蓋先端や仮声鱼症例は stage II まで照射中心，その他注手術中心とし， $\mathrm{N}_{0}$ で も予防的頸部郭清を行ない, 喉頭蓋原発症例は, 両側の 頸部郭清も必要である。Subglottic では, stage I は照 射中心，その他は手術中心とする方針で行なう。 


\section{3. 当科における喉頭癌治療成績}

間口 四郎 - 三井 博文 - 本村 昌一 - 田中 克彦

寺山 吉彦 (北海道大学・耳鼻咽喉科)

1.はじめに：喉頭癌は頭頸部腫場の中でも予後のよ いものであるが, stage III，IVでは control 不能の症例 も多く, 特に声門上癌では stage III，IVが多いことから 問題が残っている。今回我々は最近10年間の当科におけ る喉頭癌に対し統計処理を行ない，また $\mathrm{T}_{3}$ の治療法に 対して若干の考察を加えたので報告する。

2. 対 象: 対象は1972年から1981年まで当科を受診 した未治療の喉頭癌患者, 男230例，女 23 例，計 253 例で 男女比は 10 対 1 である。年齢分布は 60 歳代 $39 \% ， 50$ 歳代 29\%，70歳代19\%の順で平均63歳である。部位別では声 門癌 $37 \%$, 声門上癌 $55 \%$, 声門下癌 $8 \%$ と声門上癌が最 も多い。 stage 分類では声門癌は stage I 48\%， II 29 \%, III $21 \%$, IV $2 \%$ と stage I ，II が多く，声門上癌は stage I $18 \%$, II $11 \%$, III $34 \%$, IV $37 \%$ と stage III, IV が多い。 $N(+)$ 症例声門癌 $6 \%$ ，声門上癌 $37 \%$ と声門 上澏に多く, 発見の遅れることに加え, 本来転移しやす いためと考えられる。

3. 治 療：当科においては治療は放射線科との合同 カンファランスにて個々の症例毎に治療法を決めている が，原則的に $T_{1}, T_{2}$ 症例に対しては放射線根治照射 (5250rad/16f 7000rad/28f) ᄂ, radiation failure（以下 RF) および再発に対して salvage operation を実施して いる。 $T_{3}, T_{4}$ 症例に対しては放射線を4000 $\mathrm{rad}$ 照射し た時点で再度検討し，7000 $\mathrm{rad}$ 根治照射か，ひき続き手 術を行なう planned operation のかたちにするかを決定 している。実際に行なわれた治療は放射線根治照射後経 過観察 2 年末満のもの 40 例を除くと, 放射線根治照射の み $57 \%$, planned $10 \%$, salvage $23 \%$, 手術単独 $2 \%$, 手 術一術後照射 $6 \%$, 不十分な治療 $2 \%$ でった。手術先 行の治療法は一時期 $T_{1} T_{2}$ 症例に対して行なわれた喉 頭部切が大半を占めている。

4. 5 年生存率 : 生命表法により 5 年生存率を算出し た。声門癌は stage I $80 \%$ ，II $74 \% ，$ III $68 \%$ ，IV $0 \%$ ( 2 例), 全体で $73 \%$ であった。声門上癌は stage I 61 \%，II 73\%，III $49 \% ， I V 41 \%$ ，全体で $51 \%$ \%っった。声 門下癌は全体で $27 \%$ あった。

5. 放射線根治照射後の RF および再発：原則とし
てすべての症例に対して放射線先行治療を行なっている 当科において，今後の問題として手術に踏みきる適確な timing の決定が治療率の向上に欠かせない。放射線根 治照射後の再発は RF む含めると 7 割が 1 年以内に再 発， 9 割が 2 年以内に再発している。また放射線根治照 射の原発栄の制禦率を $\mathrm{T}_{3} \mathrm{~N}_{0}$ 症例についてみると, 声 門癌は 7 割 $(5 / 7)$ と良い一方, 声門上癌は 2 割 $(3 / 16)$ と悪く, 両者に大きな差が認められた。声門上癌 $\mathrm{T}_{4}$ が 6 割と良好なのは境界領域に発症した症例が含まれるた めと考えられる。

6. $\mathrm{T}_{3}$ の治療に対する：4000 $\mathrm{rad}$ 照射の時点で手術 に踏みきるか，根治照射にするかは当科にてしばしば直 面する問題であるが，声門癌 $T_{3}$ に対しての放射線根治 照射による制禦率は良好で, salvage は 2 例あったがど ちらも control され，今後も放射線を主体とした治療法 が良いと考えられる。一方, 声門上癌の $\mathrm{T}_{3} \mathrm{~N}_{0} \mathrm{~N}_{1}$ に 対して radiation 後経過観察のA群（放射線根治照射の み, 再発後 salvage）と, radiation 後ひき続き手術を行 なった B 群 (planned, RF 後 salvage) の 5 生率はそれ ぞれ $45 \%$ (28例), 83\% (6 例) で, Greenwood 検定に て $5 \%$ の危険率で有意差を認めた。また $\mathrm{T}_{3} \mathrm{~N}_{2} \mathrm{~N}_{3}$ の 7 症例で原発巣を根治照射のみにて制禦できたものはな かった。喉頭保存を狙ったA群において喉頭保存, 2 年 以上生存のものは 7 例で 4 分の 1 の症例に目的が達せら れたことになるが，反面，早期に手術によってほぼ同数 の症例を助け得た計算になり犠牲が大きい。放射線根治 照射のみにより治癒せしうる声門上癌 $\mathrm{T}_{3}$ 症例があるこ とは確かだが，照射後の edema 等により再発が発見し 難く, salvage のtiming が遅れてしまう危除性を内包し ていると考えられる。

7. 結論 : $\mathrm{T}_{3}$ 症例に詨しては声門癌, 声門上癌とも 手術を主体として治療する施設の報告が多いが，我々の 調查からは声門癌に対しては喉頭保存の可能性が高く， 放射線治療を主体とする治療法がよいと考えられる一 方，声門上癌ではやはり原則として手術を主体とし，放 射線は根治照射の基準を厳しくし，むしろ術前照射のか たちにすべきと考える。 


\section{4. 喉頭癌の遠隔成績}

吉積 隆・小野 勇・海老原 敏・斉藤 裕夫

（国立がんセンター病院・頭顓科）

1962年より，1977年までの16年間に当科において治療 を行った喉頭癌症例の遠隔成績について統計的観察を行 った。

対 象 : 国立がんセンター病院を受診した未治療喉頭 癌症例536 例を対象とした。扁平上皮癌以外の癌は 4 例 で, 性別では, 男性499例, 女性37例で, 男女比, 13.5: 1。年齢は, 33歳から84歳で, 60歳台にピークを示し た。原発部位別では, 声門癌327例, 声門上癌195例, 声 門下癌14例。病期別では， stage I 237例， stage II 66 例 stage III 108例, stage IV 125例。声門癌には早期例 が多く，声門上癌では進行例が多くなっている。

治療成績 : 536 例（追跡不能 3 例を含む）の 5 年粗生 率は，71\%，部位別では，声門涭79\% (stage I 85\%, stage II $71 \%$, stage III $79 \%$, stage IV $56 \%$ ), 声門上 癌 $56 \%$ (stage I $71 \%$, stage II $75 \%$, stage III $60 \%$, stage IV $42 \%$ ), 声門下癌79\%である。 5 年生存例での 喉頭保存率は，声門癌70\% (stage I 93\%, stage II 58
$\%$, stage III $22 \%$, stage IV, $0 \%$ ), 声門上癌 $47 \%$, (stage I $83 \%$, tage II $40 \%$, stage III $41 \%$, stage IV 24 $\%$ ，声門下癌18\%である。治療法別成績は表 1 亿示す。 初治療法別成績では, 部分切除が最も良く, 全摘, 放射線 治療の順となる。部分切除の適応となる症例が早期例で あること，照射例には，姑息的治療として施行されたも のや，手術拒否例に対する治療として行なわれたものが 含まれることなどから予測され得る結果である。しか し，照射後再発に対する部分切除の成績も良好であり， 初回治療としての適応搪大の余地があるとも考穴られ る。初治療後 5 年以内の死亡は154例で, 喉頭癌死77例, 死因不明28例，他病死（他癌死を含む）が49例である。 表 2 亿喉頭癌死の最終的な制禦失敗部位を示した。声門 上癌における原発单失敗例が多く，また，遠隔転移によ る死亡も 7 例中 5 例が声門上癌であり，頸部リンパ節転 移が死因となることが多い声門癌とはかなり様相が異っ ている。

表 1 Carcinoma of the larynx

Results of treatments

N.C.C.H. $1962-1977$

\begin{tabular}{l|cccccc}
\hline & P.L. & 5 Y.NED & T.L. & 5Y.NED & RAD & 5Y.NED \\
Glottic & 27 & $78 \%$ & 72 & $68 \%$ & 225 & $65 \%$ \\
Supraglottic & 14 & $86 \%$ & 60 & $58 \%$ & 120 & $32 \%$ \\
Subglottic & - & - & 9 & $67 \%$ & 5 & $40 \%$ \\
Total & & $80 \%$ & & $64 \%$ & & $53 \%$ \\
Salvage & T.L.4 & $75 \%$ & & & T.L. 67 & $75 \%$ \\
& & & & & P.L. 12 & $92 \%$ \\
& & & & & Cryo 1 & $100 \%$ \\
\hline \multicolumn{1}{c}{ Total } & 41 & $88 \%$ & 141 & $64 \%$ & 350 & $71 \%$ \\
\hline
\end{tabular}

表 2 Carcinoma of the larynx

Uncontroled sites

N.C.C.H. $1962-1977$

\begin{tabular}{c|cccc}
\hline & Glottic & Supraglottic & Subglottic & Total \\
$\mathrm{T}$ & 5 & 28 & 0 & 33 \\
$\mathrm{~N}$ & 12 & 15 & 1 & 28 \\
$\mathrm{M}$ & 2 & 5 & 0 & 7 \\
\hline Total & 19 & 48 & 1 & 68 \\
\hline
\end{tabular}

Uncontroled sites of ca. unkown: 9 cases

Glottic: 7 Subglottic: 2 


\section{5. 最近10年間の喉頭癌症例の検討}

玉虫昇・佃守・澤木 修二

（横浜市立大学・耳鼻咽喉科）

喉頭癌は耳鼻咽喉科領域の悪性腫瘍の中で最も頻度の 高いもので, 当教室入院患者の約 $9 \%$ 占めている。

1972年 1 月より 81 年12月までの10年間に当科を受診し た喉頭癌新鮮例は 226 例であった。年齢は 35 歳より 85 歳 に及び，平均63.8歳であった。男女比は8.4：1である。 このうち当科で治療及び経過観察を行いえた198例に関 して検討を加えた。

発生部位は男性では声門癌が174例中134例（72.4\%） と最も多く，女性では逆に24例中16例（66.7\%）を声門 上癌が占めている。病理組織は 1 例の線維肉腫を除き, 他は扁平上皮癌であった。

初診時主訴は，声門癌の殆では嗄声であったが，声門 上癌では曣下痛が多く, また莖部腫瘤の比率も多くなり 進んだ stage を反映していた。

i) 声門癌の治療

声門癌の初診時 Stage 分類は, Stage I 42 例, II 40 例，36例，IV 16例であった。頸部リンパ節転移は 16例 (11.9\%) にみられた。

$T_{1}$ は全例放射線の根治照射を行い，うち 3 例に局所 再発を認めたが，いずれも二次治療によって生存してい る。

$\mathrm{T}_{2}$ のらち照射に対し反応の恶い10例は喉頭全摘が施 行され, 問題なく経過している。放射線単独治療30例中, 11 例に局所再発がみられ，このうち 7 例に全摘，3例に 部分切除， 1 例再照射が行われたが， 5 例の腫癔死があ った。

$\mathrm{T}_{3}$ では遠隔転移や頸部リンパ節転移のための手術不 能例を含めて16例に放射線単独治療が行われ10例に局所 再発がみられた。全摘を行った 27 例中，気管孔周囲再発 を含めた局所再発は 8 例であった。

$\mathrm{T}_{4}$ は 5 例でいずれも全摘が行われたが， 3 例は局所 再発，1例は肺転移のため死亡している。

ii）声門上癌の治療

声門上癌は59例で, Stage I は 2 例, II 14例, III 28 例，IV 15例であった。頸部リンパ節転移は 30例で，全
体の $50.8 \%$ とかなり高率にみられた。

原発巣治療では $T_{1}, T_{2}$ の30例中，15例は放射線単独 治療が行われたが，8例 (53.3\%) と高率に原発巣再発 をみている。一方，手術例15例のうち 1 例は顓部リンパ 節転移のため死亡しているが，他は再発なく良好な経過 をたどっている。

$\mathrm{T}_{3}, \mathrm{~T}_{4}$ の進行例では付随する頚部リンパ節転移に対 する処置が予後を決める上で重要であるが，原発巣の治 療では，手術を行いえた11例中，原発巣再発は 1 例と良 好な結果をえている。但し, 放射線単独治療の場合, 18 例中11例に原発巣再発をきたしている。

iii）声門下癌の治療

声門下癌は 5 例で少く, Stage II 22 例は全摘によっ て生存。Stage III 3 例は放射線のみの一次治療後に再発 している。

iv）頚部リンパ節転移の治療

初診時，頸部リンパ節転移のあったものは46例であっ た。 $\mathrm{N}_{1}$ 例注28例であったが，このうち19例に一次治療 として原発巣とともに放射線治療を行っている。照射に より一時的な腫瘍の消失はみられるが，再発は 8 例と多 く, また再発時の致死率も高いので，今後は積極的な頸 部郭清の適応を痛感している。

v）治療成績

当教室の 10 年閒の喉頭癌全体の 5 年累積生存率は 60.7 \%であった。

声門癌の 5 生率は $66.2 \%$ で，内訳は Stage I 100\%， II $85.9 \%$, III $37.1 \%$, Stage IV は現在 5 年経過生存例は みられなかった。

声門上癌全体の 5 生率は $59.4 \%$ で, Stage I， II は $100 \%$ ，III $48.7 \% ，$ IV $22.7 \%$ であった。

他の報告に比べて進行癌の予後が悪いのは，一次治療 として放射線治療をとらざるをえない症例が多かった事 と，声門癌では気管孔周囲再発を含む局所再発が多い 事，また頸部リンパ節転移に対する頸部郭清術の適応が 少かったためと思われた。 